\title{
Empirical Study of the Influence of Consumer Relationship Proneness on Customer Loyalty in Service Context
}

\author{
Xi Feng ${ }^{12}$, Mingli Zhang ${ }^{1}$, and Jianhua Ye $^{1}$ \\ ${ }^{1}$ School of Economics and Management, Beihang University, Beijing, China \\ ${ }^{2}$ School of Science, Communication University of China, Beijing, China \\ xifengcuc@163.com
}

\begin{abstract}
Consumer relationship proneness $(C R P)$ reflects a consumer's relatively stable and conscious tendency to engage in relationships. This study takes CRP as an important consumer individual trait and examines the influence of CRP on customer loyalty in service environment from perspective of relational benefits (i.e. confidence benefits, social benefits, special treatment benefits). Concept model is proposed to explain the influence. Then SEM (structural equation modeling) is used to analyze the data collected from online survey to test the proposed model. Empirical results show that CRP has direct influence on customer loyalty. The results also show that CRP indirectly relates to customer loyalty via its impact on perceived confidence benefits and social benefits. This study deepens the understanding about the importance of CRP and provides insights into development and implement of customer relationship management and relationship marketing for service enterprises.
\end{abstract}

Keywords: consumer relationship proneness, customer loyalty, confidence benefits, social benefits, special treatment benefits

\section{Introduction}

The importance of developing and maintaining enduring relationships with customers of businesses is generally accepted in marketing literature [1]. Customer loyalty is known as a primary goal of relationship marketing and sometimes even equated with the relationship marketing concept itself due to its connection with profitability through cost reduction effects and increased revenues [2]. A key challenge for researchers is to identify and understand how managerially controlled antecedent variables influence customer loyalty.

Relational benefits represent an important approach to understand customer loyalty [1, 3, 4]. Prior research about relational benefits mainly focuses on identifying different types of relational benefits $[5,6]$ and exploring the relationship among relational benefits, relationship quality and relationship outcomes [7, 8]. Recently, some authors examine the antecedent factors affecting perceived relational benefits from different perspectives, for example, internet self-service technologies [9], customer orientation of service employees [10], effectiveness of loyalty programs [11], service provider communication style [4], while there are few attempts trying to explain indicator elements from variables reflecting consumer individual characteristics. Extant literature suggests that the success of marketing activities depends in part upon individual consumer traits and preferences [6]. Personal characteristics motivate consumers to maintain relationships [12]. There is a need to discuss the link among customer individual characteristics, customers' perceived relational benefits and customer loyalty.

Some scholars introduce the term consumer relationship proneness (CRP) to describe one type of individual difference, which reflects a consumer's relatively 
stable and conscious tendency to engage in relationships [13, 14]. CRP is a vital customer trait affecting the relationship marketing outcomes. Consumers who are inclined to engage in relationships with suppliers (i.e. relationship-prone) have higher level of trust and commitment [15].They show greater adherence to provider's requests and develop more possibility of intention to remain with firm compared to those who are not relationship-prone [16]. From a profitability perspective, it is not surprising that practitioners want to attract and retain these relationship-prone consumers [17].

Literature criticize the implementation of relationship marketing strategies without first more fully accounting for the influence of additional relationship factors and their potential performance implications [18, 19]. Researchers are suggested to examine more individual-level variables of the consumers as factors determining the maintenance of their relationship with the supplier [14, 20]. CRP is an important customer trait affecting the relationship marketing outcomes that companies strive to achieve $[13,14]$, while the potential impact of CRP upon the effectiveness of customer relationship management has not been fully explored [14, 21]. Therefore, this article seeks to further understanding of the relevance and importance of CRP to relationship marketing and customer management activities.

This study treats CRP as an important individual difference variable and examines the influence of CRP on customer loyalty in service environment from perspective of relational benefits (i.e. confidence benefits, social benefits, special treatment benefits). Specially, this research explores how CRP affects the perceived relational benefits as an antecedent variable and how CRP affects the customer loyalty via relational benefits. The authors believe that understanding of CRP can provide important insights for service providers in the successful management of customer relationships.

In the following sections, this article reviews the relevant literature of CRP, relational benefits and customer loyalty. Then the concept model about the effect of CRP on relational benefits and customer loyalty is proposed. Finally, the article offers the results of empirical study as well as management applications and directions for future research.

\section{Literature Review and Hypotheses Development}

\subsection{Customer Relationship Proneness}

Christy, Oliver, and Penn [22] use "psychologically predisposed" to express the idea that some customers are intrinsically inclined to engage in relationships than others. Compared to those "non-relationship" customers, these customers are inclined to engage in relationships. They are looking for close relationship while others prefer a short-term contact [23]. Researchers use the term relationship proneness to reflect the consumer's relatively stable and conscious tendency to engage in relationships with sellers of a particular product category [13, 14, 24]. The definition emphasizes a conscious tendency to engage in relationships as opposed to loyalty based more on inertia or convenience. It is recognized that CRP varies between customers, but there is little empirical evidence of this. However, the significance of this trait is evident for the analysis of loyalty, given that if a person is not prone to maintain a relationship with a supplier, it will be difficult to achieve his/her loyalty [25].

\subsection{Relational Benefits}

Whether the consumer would like to keep relationship with the service firms not only depends on the provided products or services, but also lies on the benefits 
consumer received in the ongoing relationship with the service businesses. These benefits have been labeled "relational benefits". Researches on relational benefits have been growing in recent years as scholars realize that understanding the benefits from the customer's perspective is as important as understanding it form the company's perspective. Gwinner et al. [6] provide the first systematic empirical work and their final quantitative study confirms three types of relationship benefits, named confidence benefits, social benefits and special treatment benefits. Subsequent quantitative studies are based on the three dimensional categorization and validate them in different circumstances $[1,5,9]$.

2.2.1. Confidence Benefits: Morgan and Hunt [26] define trust as confidence in the exchange partner's reliability and integrity, and argue that trust is a key mediating variable in relational exchanges. Confidence benefits are psychological factors related to comfort or feeling of security, reduced anxiety and trust in the service provider or the keeping promises by the provider. The sense of faith in the trustworthiness of the provider, reduced perceptions of anxiety and risk, and knowing what to expect are the most critical benefits of service relationships, and it makes customers believe that they will be treated right. Although this feeling of confidence and trust may be tied to the quality of the core service, customers still believe that it is an independent benefit coming from the long-term relationship with firms, especially when they perceive comparable service quality from other providers in the market.

2.2.2. Social Benefits: In service context, the relationship between customers and firms is always established by the contact between customers and service employees. This interpersonal contact essentially is a kind of social relation. Social benefits pertain to the emotional part of the relationship. Berry [2] presumes that social benefits include feeling of familiarity, personal recognition, friendship, rapport and social support. This type of relational benefits appears to be particularly prevalent in those services with a high degree of interpersonal contact between customers and employees. It refers to the strength of personal bonds between customers and their service employees. In some special service environment, social benefits can also arise from the relationship and friendship between customers.

2.2.3. Special Treatment Benefits: Special treatment benefits combine economic benefits and customization service. Economic benefits refer to discounts or price breaks for those customers who have developed a relationship with a provider, and also include no pecuniary benefits such as a quicker service or time saved in searching for another provider. Customization benefits include customers' perception of preferential treatment, extra attention and special services not available to other customers. Although special treat benefits are perceived as the least important of the three types of benefits across different service categories [6], high level of preferential treatment are positively influence relationship commitment, increased purchases, share of customer, word of mouth and customer feedback [7]. So the importance of the special treat benefits should not be ignored, especially for those service firms that are companied with high interpersonal contacts and have similar service performance with competitors.

\subsection{Customer Loyalty}

Customer loyalty is regarded as an essential asset of service industries in both marketing theory and practice. Early definitions of customer loyalty are solely behavioral. It focuses on a customer's repeat purchase behavior that is triggered by a marketer's activities [1]. Researchers criticize the use of solely behavior-based 
loyalty measures because this method does not distinguish between true loyalty and spurious loyalty. They suggest a two-dimensional conceptualization of loyalty adding an attitudinal dimension to the behavioral component [27]. Attitudinal loyalty is the feeling of attachment, psychological bonding, linkage to one provider and consistent regard of that provider as the preferred choice. Oliver [28] describes loyalty as a deeply held commitment to rebuy or patronize a preferred product/service consistently in the future, thereby causing repetitive purchasing despite situational influences and marketing efforts having the potential to cause switching behavior. At present, the two-dimensional conceptualization of customer loyalty is generally acknowledged in marketing research. This article uses this perspective for customer loyalty.

\subsection{CRP and Relational Benefits, Customer Loyalty}

The customer's relational tendency is of critical importance in the successful implementation of relationship marketing programs [6]. A person who is not prone to engage in a relationship with supplier has less possibility to become a loyalty consumer. Relationship-prone consumers could be more likely to recommend the provider and make positive word-of-mouth communications and to display a higher intention to stay in the relationship [25]. CRP is believed to affect the success of customer retention strategies [21]. It has a significant effect on resistance to change [17]. Parish and Holloway [16] predict a positive relationship between CRP and intention to remain with the service provider. In banking setting, employee relationship proneness is testified to be a strong trigger factor of creating employee loyalty [29]. Given that high relationship-prone consumers have a higher tendency to remain loyalty to enterprises, the authors posit the following hypothesis:

H1: CRP has a positive effect on customer loyalty.

Literature [30] indicates that consumers' interest in relationships influence perceptions of their existing relationship in a positive way. Relationship-prone consumers may perceive lower level of anxiety and frustration when they participate in loyalty programs. They may develop commercial friendship more easily and reciprocate a provider's relational efforts more strongly and favorably than nonrelationship prone consumers $[1,2,12]$. They are likely to value a customized service, mutual collaboration, confidentiality and long-term perspectives. For service firms, it is easier to establish and maintain close relationship with those relationship-prone customers. Good customer-firm relationships develop potential outcomes as reduced anxiety and risk, development of friendship, and special treatment such as customization. Consumers with high level of relationship prone are more likely to recognize relational benefits because of their greater openness toward the efforts suppliers expend to keep them [24]. Parish and Holloway [16] reveal that CRP is associated with trust and other important outcomes (e.g. share of customer and adherence). Vázquez-Carrasco and Foxall [25] find the positive relationship between CRP and relational benefits when relational benefits are treated as one dimensional concept. So the authors posit the hypotheses about the influence of CRP on three types of relational benefits:

H2a: CRP has a positive effect on perceived confidence benefits.

H2b: CRP has a positive effect on perceived social benefits.

H2c: CRP has a positive effect on perceived special treat benefits.

\subsection{Social Benefits as an Antecedent of Confidence and Special Treatment Benefits}

Gwinner et al. [6] suggest that the three benefits are likely intricately tied together. That is, there may be some positive interactions between the types of 
benefits. The intangible nature of service poses more uncertainty relating to quality and thus more risk to the customer. As customers become acquainted with the service provider and then have received social benefits, their prepurchase anxiety may decrease. The social bonding between the customer and employee can serve to increase the customer's dependence on the service provider and build the customer's trust [20]. Similarly, as employees and consumers become better acquainted, knowledge related to customization opportunities (special treatment benefits) is likely to increase. When customers have developed close relationships with the service employee (indicating more social benefits), they are likely to receive more customized services while others receive standardized services. If the customer is not personally recognized by the service employees, the customer is likely to receive less special treatment because in these cases, the customer is a mere role occupant to the employee, so that the employee has no personal feelings for the customer. Therefore, the authors propose the following hypotheses:

H3a: Perceived social benefits have a positively effect on perceived confidence benefits.

H3b: Perceived social benefits have a positively effect on perceived special treat benefits.

\subsection{Relational Benefits and Customer Loyalty}

Literatures report the existence of positive relationships between relational benefits and customer loyalty $[4,6,8,10]$. The important role of relational benefits playing in influencing consumers' loyalty intentions, word-of-mouth behavior, and commitment to the organization has been supported in recent studies. For example, Gwinner et al. [6] find that dimensions of relational benefits have significant relationships on outcomes such as loyalty and positive word-of-mouth. HennigThurau et al. [1] confirm that relational benefits positively influence customer loyalty. Yen and Gwinner [9] report that confidence and special treatment benefits mediate the impact of Internet self-service technology attributes on customer loyalty. Patterson and Smith [31] find that the loss of special treatment benefits has an especially strong impact on customer propensity to remain with service providers. Chang \& Chen [5] show that social benefits and confidence benefits had significant influences on customer loyalty from airline relational customers. Then the authors posit the following hypotheses:

H4a: Perceived confidence benefits have a positively effect on customer loyalty.

H4b: Perceived social benefits have a positively effect on customer loyalty.

H4c: Perceived special treatment benefits have a positively effect on customer loyalty.

By integrating all the hypotheses, a concept model is proposed as Figure 1.

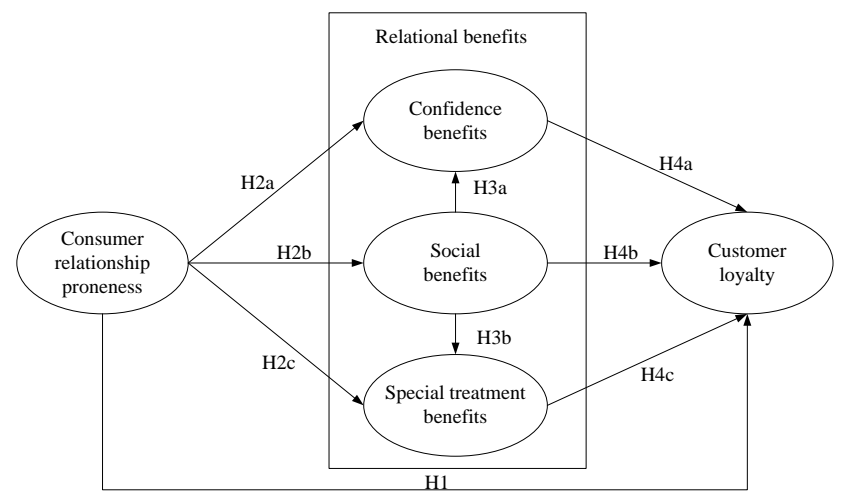

Figure 1. Concept Model 


\section{Methods}

\subsection{Measurement Instrument}

The measurement instruments were based on various valid and reliable scales. CRP was measured with 3-item instrument from Odekerken-Schröder et al. [14]. The relational benefits were operationalized by using 11 items from Gwinner et al. [6] and Hennig-Thurau et al. [1]. The confidence benefits, social benefits, and special treatment benefits were measured by 4-item, 3-item and 4-item scales respectively. Customer loyalty included attitude and behavior intentions, with 3 items from Zeithaml et al. [32]. All instruments were assessed using seven-point Likert scale ranging from 1 (completely disagree) to 7 (completely agree).

\subsection{Data Collection}

The study collected data using an online survey with the assistance of a market research company. The final questionnaire uploaded consisted three parts. First, the respondents were asked whether they are regular customers of service companies. If their answers were positive, they were required to indicate one service company that they have long relationship with. According to their experience with the service provider, they began to fill out the second part of the survey. The second part was to measure the main variables in this research, including CRP, perceived relational benefits and customer loyalty. Then the questionnaire gathered the information about the respondents' demographic statistics characteristics.

Finally 332 respondents completed the survey. After eliminating those with invalid information, 269 questionnaires remained for analysis, representing a rate of $81 \%$ for useful responses. More than half of the participants were female $(56.5 \%)$. Over $80 \%$ respondents chose restaurant or hairdresser services as their constantly consuming providers. These two types of providers represent the typical characteristics of traditional service industries.

\section{Data Analysis and Results}

\subsection{Measurement Model Results}

SPSS 17.0 and LISREL 8.70 were used to analyze the data. All measures were first subjected to exploratory factor analysis and then to confirmatory factor analysis. Exploratory factor analysis results confirmed the conceptual structure proposed in the model. Cronbach's alpha indicated that the scales could be used with all reliabilities above 0.7 (see Table 1 ). Thus the scales were uni-dimensional. Confirmatory factor analysis with LISREL supported the fit of the measurement model and found all items to serve as strong measures of their respective construct $\left(\chi^{2}=208.9, \quad \mathrm{df}=109, \mathrm{p}<0.05, \mathrm{RMSEA}=0.058, \mathrm{GFI}=0.92, \mathrm{AGFI}=0.88, \mathrm{CFI}=0.99\right.$, NNFI=0.98).

Convergent validity was supported by an acceptable result. Almost all factor loadings were greater than 0.5 (except one item of CRP's loading equals to 0.5 ) and statistically significant. The AVE (average variance extracted) value for each dimension was greater than the reference value of 0.5. Composite reliability was used to analyze the reliability of the constructs. All constructs were reliable because the CR (composite reliability) values exceed the threshold of 0.7 (see Table 1). 
Table 1. Measurement Model Results

\begin{tabular}{|c|c|c|c|c|c|}
\hline Construct & Scale Items & loading & $\mathrm{CR}$ & Cronbach $\alpha$ & AVE \\
\hline \multirow{3}{*}{ CRP } & $\begin{array}{l}\text { Generally, I am someone who likes to be a } \\
\text { regular customer of a service provider. }\end{array}$ & 0.92 & \multirow{3}{*}{0.83} & \multirow{3}{*}{0.79} & \multirow{3}{*}{0.64} \\
\hline & $\begin{array}{l}\text { Generally, I am someone who wants to be a } \\
\text { regular customer. }\end{array}$ & 0.91 & & & \\
\hline & $\begin{array}{l}\text { Generally, I am someone who is willing to } \\
\text { "go the extra mile" to buy at the same } \\
\text { provider. }\end{array}$ & 0.50 & & & \\
\hline \multirow{4}{*}{$\begin{array}{l}\text { Confidence } \\
\text { Benefits }\end{array}$} & $\begin{array}{l}\text { I believe there is less risk that something } \\
\text { will go wrong. }\end{array}$ & 0.84 & \multirow{4}{*}{0.91} & \multirow{4}{*}{0.91} & \multirow{4}{*}{0.73} \\
\hline & I have less anxiety when I buy the service. & 0.91 & & & \\
\hline & $\begin{array}{l}\text { I have more confidence the service will be } \\
\text { performed correctly. }\end{array}$ & 0.86 & & & \\
\hline & I feel I can trust the employee(s). & 0.80 & & & \\
\hline \multirow{3}{*}{$\begin{array}{l}\text { Social } \\
\text { benefits }\end{array}$} & I am recognized by (a) certain employee(s). & 0.79 & \multirow{3}{*}{0.87} & \multirow{3}{*}{0.86} & \multirow{3}{*}{0.69} \\
\hline & $\begin{array}{l}\text { I have developed a friendship with the } \\
\text { employee(s). }\end{array}$ & 0.87 & & & \\
\hline & $\begin{array}{l}\text { I enjoy certain social aspects of the } \\
\text { relationship. }\end{array}$ & 0.83 & & & \\
\hline \multirow{4}{*}{$\begin{array}{l}\text { Special } \\
\text { treatment } \\
\text { benefits }\end{array}$} & $\begin{array}{l}\text { I receive better prices or special deals that } \\
\text { most customers don't have. }\end{array}$ & 0.83 & \multirow{4}{*}{0.94} & \multirow{4}{*}{0.94} & \multirow{4}{*}{0.80} \\
\hline & $\begin{array}{l}\text { I receive faster service than most other } \\
\text { customers. }\end{array}$ & 0.92 & & & \\
\hline & $\begin{array}{l}\text { They provide services to me that they don't } \\
\text { do provide to most other customers }\end{array}$ & 0.94 & & & \\
\hline & $\begin{array}{l}\text { I am placed higher on the priority list when } \\
\text { there is a line. }\end{array}$ & 0.88 & & & \\
\hline \multirow{3}{*}{$\begin{array}{l}\text { Customer } \\
\text { loyalty }\end{array}$} & $\begin{array}{l}\text { I will continue to buy the service of this } \\
\text { provider. }\end{array}$ & 0.92 & \multirow{3}{*}{0.90} & \multirow{3}{*}{0.89} & \multirow{3}{*}{0.76} \\
\hline & $\begin{array}{l}\text { When I need to make a purchase, this } \\
\text { provider is my first choice. }\end{array}$ & 0.91 & & & \\
\hline & $\begin{array}{l}\text { When someone asks me, I will say positive } \\
\text { things about this provider. }\end{array}$ & 0.77 & & & \\
\hline
\end{tabular}

To assess discriminant validity, the study compared the AVE of each construct with the variance shared between each construct and the other constructs of the model. The square root of the AVE was greater than the correlations between constructs, which confirmed the existence of discriminant validity (see Table 2).

Table 2. Discriminant Validity Results

\begin{tabular}{|c|c|l|l|c|c|}
\hline Constructs & CRP & $\begin{array}{l}\text { Confidence } \\
\text { benefits }\end{array}$ & $\begin{array}{l}\text { Social } \\
\text { benefits }\end{array}$ & $\begin{array}{c}\text { Special } \\
\text { treatment } \\
\text { benefits }\end{array}$ & $\begin{array}{l}\text { Customer } \\
\text { loyalty }\end{array}$ \\
\hline CRP & 0.80 & & & & \\
\hline Confidence benefits & 0.41 & 0.85 & & & \\
\hline Social benefits & 0.41 & 0.56 & 0.83 & & \\
\hline $\begin{array}{c}\text { Special treatment } \\
\text { benefits }\end{array}$ & 0.31 & 0.36 & 0.75 & 0.89 & \\
\hline Customer Loyalty & 0.45 & 0.76 & 0.57 & 0.42 & 0.87 \\
\hline
\end{tabular}

Notes: Diagonal elements show the square root of AVE of each construct; the other figures correspond to the correlations between the constructs.

\subsection{Structural Model Results}

The hypotheses of structural model were tested using SEM (structural equation modeling) with LISREL 8.70. The results demonstrated an acceptable overall fit with the data, producing fits indices of $\chi^{2}=212.31, d f=110$, RMSEA $=0.06$, $\mathrm{GFI}=0.91, \mathrm{AGFI}=0.88, \mathrm{IFI}=0.99, \mathrm{NNFI}=0.98$. The $\chi^{2} / d f$ ratio was equal to 1.93 with 
ratios under 3 indicating acceptable fit. The standardized parameter estimates and tvalues are reported in Table 3 .

The results indicate that $\mathrm{CRP}$ has significant influence on customer loyalty $(\beta=0.12, \mathrm{t}=2.38, \mathrm{p}<0.05)$, which supports H1. CRP positively relates to perceived confidence benefits $(\beta=0.23, \mathrm{t}=3.52, \mathrm{p}<0.001)$ and social benefits $(\beta=0.4, \mathrm{t}=5.96$, $\mathrm{p}<0.001$ ), which supports $\mathrm{H} 2 \mathrm{a}$ and $\mathrm{H} 2 \mathrm{~b}$. But the path from CRP to special treatment benefits is not statistical significant $(\beta=0.01, t=0.14)$, so $H 2 c$ is denied. As predicted in $\mathrm{H} 3 \mathrm{a}$ and $\mathrm{H} 3 \mathrm{~b}$, social benefits are positively related to perception of confidence benefits $(\beta=0.47, t=6.60, p<0.001)$ and special treatment benefits $(\beta=0.74, t=10.27$, $\mathrm{p}<0.001)$. Confidence benefits has positive influences on customer loyalty $(\beta=0.59$, $\mathrm{t}=9.47, \mathrm{p}<0.001$ ), which supports H4a. Social benefits are marginally related to customer loyalty $(\beta=0.15, \mathrm{t}=1.68, \mathrm{p}<0.1)$, which supports $\mathrm{H} 4 \mathrm{~b}$. While the link between special treatment benefits and customer loyalty $(\beta=0.05, t=0.61)$ is statistically insignificant, so $\mathrm{H} 4 \mathrm{c}$ is not supported.

\section{Table 3. Results of Structural Model}

\begin{tabular}{|l|c|c|c|}
\hline Hypothesized relationship & $\begin{array}{l}\text { Standardized } \\
\text { path }\end{array}$ & T value & $\begin{array}{l}\text { Hypotheses } \\
\text { supported } \\
\text { yes/no }\end{array}$ \\
\hline H1: CRP $\rightarrow$ Customer loyalty & 0.12 & 2.38 & Yes \\
\hline H2a: CRP $\rightarrow$ Confidence benefits & 0.23 & 3.52 & Yes \\
\hline H2b: CRP $\rightarrow$ Social benefits & 0.40 & 5.96 & Yes \\
\hline H2c: CRP $\rightarrow$ Special treatment benefits & 0.01 & 0.14 & No \\
\hline H3a: Social benefits $\rightarrow$ Confidence benefits & 0.47 & 6.60 & Yes \\
\hline H3b: Social benefits $\rightarrow$ Special treatment benefits & 0.74 & 10.27 & Yes \\
\hline H4a: Confidence benefits $\rightarrow$ Customer loyalty & 0.59 & 9.47 & Yes \\
\hline H4b: Social benefits $\rightarrow$ Customer loyalty & 0.15 & 1.68 & Yes \\
\hline $\begin{array}{l}\text { H4c: Special treatment benefits } \rightarrow \text { Customer } \\
\text { loyalty }\end{array}$ & 0.05 & 0.61 & No \\
\hline
\end{tabular}

Table 4 reports the indirect and total effects of CRP on relational benefits and customer loyalty. Results confirm that CRP has significant indirect effect on customer loyalty via its influence on relational benefits.

Table 4. Effects of CRP on Other Constructs

\begin{tabular}{|c|c|c|c|}
\hline CRP & Direct effect & Indirect effect & Total effect \\
\hline Confidence benefits & $0.23(3.52)$ & $0.19(4.65)$ & $0.42(6.26)$ \\
\hline Social benefits & $0.40(5.96)$ & - & $0.4(5.96)$ \\
\hline $\begin{array}{c}\text { Special treatment } \\
\text { benefits }\end{array}$ & $0.01(0.14)$ & $0.3(5.45)$ & $0.31(4.72)$ \\
\hline Customer Loyalty & $0.12(2.38)$ & $0.32(6.27)$ & $0.44(7.00)$ \\
\hline
\end{tabular}

Notes: Figures in round brackets correspond to $\mathrm{T}$ value.

\section{Discussion and Implication}

\subsection{Discuss of Results}

The purpose of this research is to increase understanding of the relevance and importance of CRP to relationship marketing and customer management activities. The authors develop one model explaining customer loyalty from the CRP's viewpoint. The study takes CRP as an important individual trait and verifies its direct influence towards 
customer loyalty. Meanwhile, this study explores the impact of CRP on three types of customer perceived relational benefits. Results report the direct association between CRP and perceived confidence benefits and social benefits. However, the study does not find a significant effect of CRP on special treatment benefits. The possible reason may be that customers with high level of CRP may care more for the relational/social aspects of the service process than special treatment they get form service exchange.

\subsection{Management Implication}

In today's consumer-centric era, relationship management is becoming increasingly important and service practitioners have transferred their attention from service quality towards a relationship marketing approach. This study not only verifies theoretical conceptions regarding CRP and demonstrates its effect on perceived relational benefits and customer loyalty, but also provides insights into the implement and development of customer relationship management for service providers.

In order to retain customers, loyalty programs are generally employed. While companies find that the results are not satisfactory even if significant resources and costs involved in relationship marketing. It may due to the practitioner's failing to pay attention to the efficiency issue of marketing tactics, especially form the view point of individual differences. Actually, the relational approach is inappropriate to apply to all circumstances, since not all customers appreciate relational treatment. Some customers may prefer approaches that are based on minimization of costs and offered by discount brokers.

The findings confirm and reinforce the major results of the previous research that CRP is an instrumental element of the service exchange, directly affecting the success of relationship marketing tactics. Considering its variation among different individuals, managers need to seek a great understanding of individual consumer differences and identify CRP in order to better managing customer relationships.

It is suggested that service providers should screen potential loyalty customers on their CRP in addition to more traditional indicators such as age, gender, and incoming. Although CRP will be less tangible than the demographic information, it will be worth the effort. Practitioners can use loyalty programs, in-store credit programs and websites to offer opportunities to capture such information about customers and incorporate it into increasingly customized strategies and communications.

Customers with high level relationship prone are likely easy to maintain long relationships with service providers. Because the relationship-prone consumers have a high tendency to act upon the personal characteristics, segmenting consumers according to level of CRP could affect expected share of market and share of customer values. This suggestion is in line with the remarks of Söllner [33], who holds the idea that careful customer segmentation has to be carried out in order to identify clients who may have opportunities to be loyal.

Measurement of CRP can provide firms with an enhanced ability to target the "right" customers, because those customers who are more prone to relationships may be less expensive to attract and to retain over time. Not every customer is willing to engage in long-term relationships and therefore the providers should not waste resources on targeting those unwilling customers. So measuring CRP provides a practical element for segmentation of relational-type customers vs non-relational-type customers. It must be taken into account before deciding which type of marketing approach to apply: relational or transactional.

According to these points, companies should provide differential treatment depending on the targeted market segment based CRP. For those relational-prone customers, the personal contact and intimacy of encounters should be reinforced to reap the larger benefits of CRP. Employees should be encouraged to keep contact, increase communication, show concerns and establish friendship with customers in 
service process. Personal interactions constitute a pivotal aspect of service context. This kind of social bond is useful as a differentiation strategy for its difficulty for other competitors to replicate. To attract those relational-type consumers, employees should create an environment in which its customers have the opportunity to establish warm relationships with the providers. For the non-relational customers, companies should pay more attention to offer their economic advantages, such as special pricing considerations, different level of discount according to the length of relationships and free service/goods on customer's birthday.

\section{Limitations and Directions for Future Research}

The authors realize that there are some limitations of this study and consequent opportunities for further research. First, the majority of the respondents in this research choose the traditional service providers (restaurant and hairdressing) as their reference. Therefore the results are applicable more to the relational service context. It would be interesting to apply the same model to more transactional service setting. Dose the nature of the service exchange (transactional versus relational) affect the association among CRP, relational benefits and customer loyalty? Second, the data focus on the online survey. Offline respondents will be an executable way to gain the additional research samples. Third, future research might include other individual difference variables such as self-efficacy, variety seeking and extroversion. Fourth, the study focuses relationship proneness from customer's view of point, and it would be desirable to analyze employee relationship proneness. Whether employee relationship proneness will play an important role in generating customer loyalty via enhance customers' perceived relational benefits? How the effect acts? The answers to these questions could open an attractive area for both literature and practice to relationship management and service marketing.

\section{Acknowledgements}

This research is supported by the National Science Foundation of China (No. 71272018).

\section{References}

[1] T. Hennig-Thurau, K. P. Gwinner and D. D. Gremler. "Understanding relationship marketing outcomes an integration of relational benefits and relationship quality", Journal of Service Research, vol. 4, no. 3, (2002).

[2] L. L. Berry, "Relationship marketing of services-growing interest, emerging perspectives", Journal of the Academy of Marketing Science, vol. 23, no. 4, (1995).

[3] T. Hennig-Thurau, K. P. Gwinner, D. D. Gremler and M. Paul, "Managing service relationships in a global economy: exploring the impact of national culture on the relevance of customer relational benefits for gaining loyal customers", Advances in International Marketing, vol. 15, (2005).

[4] I. Kim, S. M. Jeon and S. S.Hyun, "The role of effective service provider communication style in the formation of restaurant patrons' perceived relational benefits and loyalty", Journal of Travel \& Tourism Marketing, vol. 28, no.7, (2011).

[5] Y. H. Chang and F. Y. Chen, "Relational benefits, switching barriers and loyalty: A study of airline customers in Taiwan", Journal of Air Transport Management, vol. 13, no. 2, (2007).

[6] K. P. Gwinner, D. D. Gremler, and M. J. Bitner, "Relational benefits in services industries: the customer's perspective", Journal of the Academy of Marketing Science, vol. 26, no. 2, (1998).

[7] R. Lacey, J. Suh and R. M. Morgan, "Differential effects of preferential treatment levels on relational outcomes", Journal of Service Research, vol. 9, no. 3, (2007).

[8] A. Molina, D. Martín-Consuegra and À. Esteban, "Relational benefits and customer satisfaction in retail banking", International Journal of Bank Marketing, vol. 25, no. 4, (2007).

[9] H. J. R. Yen and K. P. Gwinner, "Internet retail customer loyalty: the mediating role of relational benefits", International Journal of Service Industry Management, vol. 14, no. 5, (2003).

[10] W. Kim, "Customers' responses to customer orientation of service employees in full - service restaurants: a relational benefits perspective", Journal of Quality Assurance in Hospitality \& Tourism, vol. 10, no. 3, (2009). 
[11] T. Saili, Z. Mingli and C. Zhichao, "The effects of loyalty programs on customer loyalty: The mediating role of customer value and the moderating role of relationship benefits", African Journal of Business Management, vol. 6, no. 11, (2012).

[12] K. E. Reynolds and S. E. Beatty, "Customer benefits and company consequences of customersalesperson relationships in retailing", Journal of Retailing, vol. 75, no. 1, (1999).

[13] K. De Wulf, G. Odekerken-Schröder and D. Iacobucci, "Investments in consumer relationships: a crosscountry and cross-industry exploration", Journal of Marketing, (2001).

[14] G. Odekerken-Schröder, K. De Wulf and P. Schumacher, "Strengthening outcomes of retailer-consumer relationships: The dual impact of relationship marketing tactics and consumer personality", Journal of Business Research, vol. 56, no. 3, (2003).

[15] N. Hedrick, M. Beverland and S. Minahan, "An exploration of relational customers' response to service failure", Journal of Services Marketing, vol. 21, no. 1, (2007).

[16] J. T. Parish and B. B. Holloway, "Consumer relationship proneness: a reexamination and extension across service exchanges”, Journal of Services Marketing, vol. 24, no. 1, (2010)

[17] H. Y. Kim, J. Y. M. Kang and K. K. Johnson, "Effect of consumer relationship proneness on perceived loyalty program attributes and resistance to change", International Journal of Retail \& Distribution Management, vol. 40, no. 5, (2012).

[18] K. Atuahene-Gima and H. Li, "When does trust matter? Antecedents and contingent effects of supervisee trust on performance in selling new products in China and the United States", Journal of Marketing, (2002).

[19] I. Geyskens, J. B. E. Steenkamp and N. Kumar, "Generalizations about trust in marketing channel relationships using meta-analysis", International Journal of Research in Marketing, vol. 15, no. 3, (1998).

[20] N. Bendapudi and L. L. Berry, "Customers' motivations for maintaining relationships with service providers", Journal of Retailing, vol. 73, no. 1, (1997).

[21] J. N. Sheth and A. Parvatlyar, "Relationship marketing in consumer markets: antecedents and consequences", Journal of the Academy of Marketing Science, vol. 23, no. 4, (1995).

[22] R. Christy, G. Olive and J. Penn, "Relationship marketing in consumer markets", Journal of Marketing Management, vol. 12, no. 1, (1996).

[23] D. E. Sheaves and J. G. Barnes, "The fundamentals of relationships: an exploration of the concept to guide marketing implementation", Advances in Services Marketing and Management, vol. 5, (1996).

[24] J. Bloemer, G. Odekerken-Schröder and L. Kestens, "The impact of need for social affiliation and consumer relationship proneness on behavioural intentions: an empirical study in a hairdresser's context", Journal of Retailing and Consumer Services, vol. 10, no. 4, (2003).

[25] R. Vázquez-Carrasco and G. R. Foxall, "Influence of personality traits on satisfaction, perception of relational benefits, and loyalty in a personal service context", Journal of Retailing and Consumer Services, vol. 13 , no. 3, (2006).

[26] R. M. Morgan and S. D. Hunt, "The commitment-trust theory of relationship marketing", Journal of Marketing, (1994).

[27] G. S. Day, "A two-dimensional concept of brand loyalty", Journal of Advertising Research, vol. 9, (1969).

[28] R. L. Oliver, “Whence consumer loyalty?", Journal of Marketing, (1999).

[29] J. Bloemer and G. Odekerken-Schröder, "The role of employee relationship proneness in creating employee loyalty”, International Journal of Bank Marketing, vol. 24, no. 4, (2006).

[30] K. Storbacka, T. Strandvik and C. Grönroos, "Managing customer relationships for profit: the dynamics of relationship quality", International Journal of Service Industry Management, vol. 5, no. 5, (1994).

[31] P. G. Patterson and T. Smith, "A cross-cultural study of switching barriers and propensity to stay with service providers", Journal of Retailing, vol. 79, no. 2, (2003).

[32] V. A. Zeithaml, L. L. Berry and A. Parasuraman, "The behavioral consequences of service quality", Journal of Marketing, (1996).

[33] A. Söllner, "Asymmetrical commitment in business relationships", Journal of Business Research, vol. 46, no. 3, (1999).

\section{Authors}

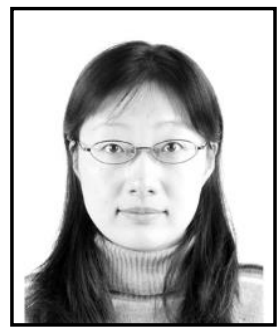

Xi Feng, she received the M. SC. Degree in Probability and Statistics from Beijing University of Technology (2003). Now she is a PhD candidate of Beihang University and a full lecturer at School of Science, Communication University of China. Her current research interests include service marketing and consumer behavior. 


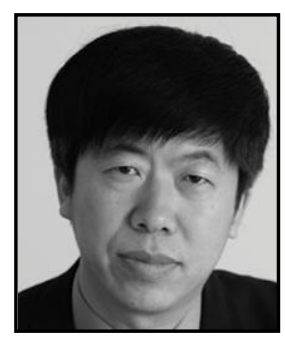

Mingli Zhang, Ph.D., Doctoral tutor, Professor of School of Economics and Management, Beihang University, executive director of China Marketing Association. His main research fields include service marketing, brand management, customer value and consumer behavior.

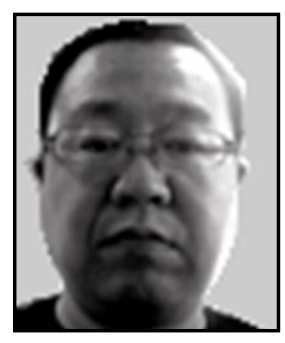

Jianhua Ye, he received the M. SC. Degree in Marketing from Harbin Institute of Technology (2004). Now he is a PhD candidate of Beihang University. His current research interests include relationship marketing and relationship value. 